\title{
Optimization of Culture Conditions (Sucrose, pH, and Photoperiod) for In Vitro Regeneration and Early Detection of Somaclonal Variation in Ginger Lime (Citrus assamensis)
}

\author{
Jamilah Syafawati Yaacob, ${ }^{1,2}$ Noraini Mahmad, ${ }^{1}$ Rosna Mat Taha, ${ }^{1}$ Normadiha Mohamed, ${ }^{1}$ \\ Anis Idayu Mad Yussof, ${ }^{1}$ and Azani Saleh ${ }^{1,3}$ \\ ${ }^{1}$ Institute of Biological Sciences, Faculty of Science, University of Malaya, 50603 Kuala Lumpur, Malaysia \\ ${ }^{2}$ Centre for Research in Biotechnology for Agriculture, Institute of Biological Sciences, Faculty of Science, University of Malaya, \\ 50603 Kuala Lumpur, Malaysia \\ ${ }^{3}$ Faculty of Applied Science, MARA University of Technology, 40450 Shah Alam, Selangor, Malaysia
}

Correspondence should be addressed to Jamilah Syafawati Yaacob; jam_sya@yahoo.com

Received 8 November 2013; Accepted 29 January 2014; Published 1 April 2014

Academic Editors: H. P. Bais and A. Ouwehand

Copyright (C) 2014 Jamilah Syafawati Yaacob et al. This is an open access article distributed under the Creative Commons Attribution License, which permits unrestricted use, distribution, and reproduction in any medium, provided the original work is properly cited.

\begin{abstract}
Various explants (stem, leaf, and root) of Citrus assamensis were cultured on MS media supplemented with various combinations and concentrations $\left(0.5-2.0 \mathrm{mgL}^{-1}\right)$ of NAA and BAP. Optimum shoot and root regeneration were obtained from stem cultures supplemented with $1.5 \mathrm{mgL}^{-1} \mathrm{NAA}$ and $2.0 \mathrm{mgL}^{-1} \mathrm{BAP}$, respectively. Explant type affects the success of tissue culture of this species, whereby stem explants were observed to be the most responsive. Addition of $30 \mathrm{gL}^{-1}$ sucrose and $\mathrm{pH}$ of 5.8 was most optimum for in vitro regeneration of this species. Photoperiod of 16 hours of light and 8 hours of darkness was most optimum for shoot regeneration, but photoperiod of 24 hours of darkness was beneficial for production of callus. The morphology (macro and micro) and anatomy of in vivo and in vitro/ex vitro Citrus assamensis were also observed to elucidate any irregularities (or somaclonal variation) that may arise due to tissue culture protocols. Several minor micromorphological and anatomical differences were observed, possibly due to stress of tissue culture, but in vitro plantlets are expected to revert back to normal phenotype following full adaptation to the natural environment.
\end{abstract}

\section{Introduction}

Citrus assamensis is a member of Rutaceae, an important underexploited, hybrid, evergreen, and aromatic tree. Citrus sp. is very attractive due to their distinctive fruits, colours, and attractive smell, unique from other plants. Containing high amounts of vitamin C, citrus fruits can be consumed raw or extracted for production of highly nutritious beverages. The percentage of citrus juice is an extremely important parameter for its industrial processing, being also related to fruit size [1]. Furthermore, Citrus sp. can also be used as traditional medicine, whereby the smell of citrus leaves and fruits can overcome headache and nausea. Tissue culture of Citrus sp. is very important to increase the production and mass propagation of this valuable plant. The use of tissue culture in the breeding of Citrus sp. is essential as it has the potential to overcome infertility of citrus seeds due to fungal infections by Fusarium, Rhizoctonia, and Sclerotium. Fungal infections caused the citrus seeds to be damaged before they can be germinated [2]. Citrus is generally propagated through budding, cutting, or layering. Therefore, propagation is limited to the period when buds are available [3].

In vitro micropropagation technology can overcome some constraints to Citrus improvement and cultivation and can increase fruit quality and resistance to disease and environmental stresses [4]. The size of the fruit is important not only because it is a component of productive yield but also because it determines the acceptance and demand by the consumers. The application of plant growth regulators can reenforce hormone balance in the peel, reducing or 
TABLE 1: The effects of different combinations and concentrations of BAP and NAA on stem explants of Citrus hybrids, cultured on solid MS media at $25 \pm 1^{\circ} \mathrm{C}$. Cultures were maintained at 16 hours of light and 8 hours of darkness, with 1000 lux intensity of light.

\begin{tabular}{|c|c|c|c|c|c|}
\hline \multicolumn{2}{|c|}{ MS + hormone } & \multirow{2}{*}{ Observations } & \multirow{2}{*}{ Callus (\%) } & \multicolumn{2}{|c|}{ Organogenesis } \\
\hline $\mathrm{BAP}\left(\mathrm{mgL}^{-1}\right)$ & $\mathrm{NAA}\left(\mathrm{mgL}^{-1}\right)$ & & & Shoot $(\%)$ & Root $(\%)$ \\
\hline 0.0 & 1.0 & $\begin{array}{l}\text { White callus formation after } 20 \text { days } \\
\text { Root formation after } 30 \text { days }\end{array}$ & $73.3 \pm 0.6^{\mathrm{ef}}$ & NR & $26.7 \pm 0.6^{a}$ \\
\hline 0.0 & 2.0 & $\begin{array}{l}\text { White callus formation after } 15 \text { days } \\
\text { Root formation after } 30 \text { days }\end{array}$ & $80.0 \pm 5.8^{\mathrm{fg}}$ & NR & $26.7 \pm 1.7^{\mathrm{a}}$ \\
\hline 1.0 & 0.0 & Shoot formation after 55 days & NR & $20.0 \pm 2.9^{\mathrm{a}}$ & NR \\
\hline 2.0 & 0.0 & Shoot formation after 55 days & NR & $20.0 \pm 5.8^{\mathrm{a}}$ & NR \\
\hline 0.5 & 0.5 & $\begin{array}{l}\text { Green callus formation after } 16 \text { days } \\
\text { Shoot formation after } 60 \text { days }\end{array}$ & $80.0 \pm 2.9^{\mathrm{fg}}$ & $20.0 \pm 1.2^{\mathrm{a}}$ & NR \\
\hline 1.0 & 0.5 & $\begin{array}{l}\text { Greenish callus formation after } 30 \text { days } \\
\text { Shoot formation after } 58 \text { days }\end{array}$ & $66.7 \pm 1.2^{\mathrm{de}}$ & $20.0 \pm 2.9^{\mathrm{a}}$ & NR \\
\hline 1.5 & 0.5 & Greenish callus formation after 16 days & $53.3 \pm 1.7^{\mathrm{cd}}$ & NR & NR \\
\hline 2.0 & 0.5 & $\begin{array}{l}\text { Greenish callus formation after } 25 \text { days } \\
\text { Shoot formation after } 58 \text { days }\end{array}$ & $60.0 \pm 5.8^{\text {cde }}$ & $20.0 \pm 2.3^{\mathrm{a}}$ & NR \\
\hline 0.5 & 1.0 & $\begin{array}{l}\text { Greenish callus formation after } 20 \text { days } \\
\text { Shoot formation after } 35 \text { days }\end{array}$ & $86.7 \pm 2.3^{\mathrm{gh}}$ & $20.0 \pm 0.6^{\mathrm{a}}$ & NR \\
\hline 1.0 & 1.0 & Greenish callus formation after 28 days & $46.7 \pm 0.6^{b c}$ & NR & NR \\
\hline 1.5 & 1.0 & $\begin{array}{l}\text { Yellowish callus formation after } 28 \text { days } \\
\text { Shoot formation after } 50 \text { days }\end{array}$ & $26.7 \pm 3.8^{\mathrm{a}}$ & $20.0 \pm 7.5^{\mathrm{a}}$ & NR \\
\hline 2.0 & 1.0 & Greenish callus formation after 30 days & $33.3 \pm 5.7^{\mathrm{ab}}$ & NR & NR \\
\hline 0.5 & 1.5 & Green callus formation after 20 days & $100.0 \pm 0.0^{\mathrm{h}}$ & NR & NR \\
\hline 1.0 & 1.5 & $\begin{array}{l}\text { Green callus formation after } 30 \text { days } \\
\text { Shoot formation after } 50 \text { days }\end{array}$ & $33.3 \pm 2.3^{\mathrm{ab}}$ & $20.0 \pm 1.2^{\mathrm{a}}$ & NR \\
\hline 1.5 & 1.5 & Greenish callus formation after 21 days & $73.3 \pm 2.3^{\mathrm{efg}}$ & NR & NR \\
\hline 2.0 & 1.5 & $\begin{array}{l}\text { Green callus formation after } 25 \text { days } \\
\text { Shoot formation after } 30 \text { days }\end{array}$ & $33.3 \pm 1.2^{\mathrm{ab}}$ & $46.7 \pm 5.2^{\mathrm{b}}$ & NR \\
\hline 0.5 & 2.0 & $\begin{array}{l}\text { Green callus formation after } 18 \text { days } \\
\text { Shoot formation after } 40 \text { days }\end{array}$ & $73.3 \pm 4.6^{\mathrm{efg}}$ & $20.0 \pm 2.9^{\mathrm{a}}$ & NR \\
\hline 1.0 & 2.0 & $\begin{array}{l}\text { Green callus formation after } 20 \text { days } \\
\text { Shoot formation after } 50 \text { days }\end{array}$ & $46.7 \pm 4.0^{b c}$ & $20.0 \pm 1.2^{\mathrm{a}}$ & NR \\
\hline 1.5 & 2.0 & $\begin{array}{l}\text { Yellow callus formation after } 18 \text { days } \\
\text { Shoot formation after } 55 \text { days }\end{array}$ & $60.0 \pm 11.5^{\text {cde }}$ & $20.0 \pm 3.5^{\mathrm{a}}$ & NR \\
\hline 2.0 & 2.0 & $\begin{array}{l}\text { Green callus formation after } 18 \text { days } \\
\text { Shoot formation after } 38 \text { days }\end{array}$ & $86.7 \pm 5.8^{\mathrm{gh}}$ & $26.7 \pm 1.7^{\mathrm{a}}$ & NR \\
\hline 3.0 & 3.0 & Yellowish callus formation after 28 days & $46.7 \pm 5.8^{b c}$ & NR & NR \\
\hline
\end{tabular}

Mean \pm SE, $n=30$. Mean values with different letters in the same column are significantly different at $P<0.05$ (NR: no response).

retarding precocious fall and unwelcome losses at harvest [5]. Very few literatures were found on in vitro regeneration of Citrus sp., particularly on Citrus assamensis. To the best of our knowledge, this is the first report describing the effects of different plant growth regulators on micropropagation of this species. The current study aimed to determine the optimum hormone for efficient regeneration of Citrus assamensis and study the effect of sucrose concentraion, $\mathrm{pH}$ of the media, and photoperiod on organogenesis and callogenesis of this species. Ultimately, SEM and some histological studies were carried out on in vitro regenerants and compared with intact plants to detect early occurrence of somaclonal variation.

\section{Materials and Methods}

2.1. Effects of Different Concentrations and Combinations of NAA and BAP on Callogenesis and Organogenesis of Citrus assamensis. Seeds of Citrus assamensis obtained from "Rimba Ilmu" or botanical garden of University of Malaya, Malaysia, were first washed with nondiluted teepol, followed by tap water. The seeds were then sterilised with $99 \%(\mathrm{v} / \mathrm{v})$ sodium hypochlorite solution for $1 \mathrm{~min}$ and rinsed three times with distilled water. In a laminar flow chamber, the seeds were dipped in $70 \%$ (v/v) ethanol for $1 \mathrm{~min}$, blotted with sterile tissue paper, and cultured on solid MS basal media [6] to produce aseptic seedlings. The media were added with 
TABLE 2: The effects of different combinations and concentrations of BAP and NAA on root explants of Citrus hybrids, cultured on solid MS media at $25 \pm 1^{\circ} \mathrm{C}$. Cultures were maintained at 16 hours of light and 8 hours of darkness, with 1000 lux intensity of light.

\begin{tabular}{|c|c|c|c|c|c|}
\hline \multicolumn{2}{|c|}{ MS + hormone } & \multirow{2}{*}{ Observations } & \multirow{2}{*}{ Callus (\%) } & \multicolumn{2}{|c|}{ Organogenesis } \\
\hline $\operatorname{BAP}\left(\mathrm{mgL}^{-1}\right)$ & $\mathrm{NAA}\left(\mathrm{mgL}^{-1}\right)$ & & & Shoot $(\%)$ & Root $(\%)$ \\
\hline 0.0 & 1.0 & $\begin{array}{l}\text { White callus formation after } 35 \text { days } \\
\text { Root formation after } 35 \text { days }\end{array}$ & $46.7 \pm 1.2^{\mathrm{ab}}$ & NR & $20.0 \pm 1.7^{\mathrm{a}}$ \\
\hline 0.0 & 2.0 & $\begin{array}{l}\text { White callus formation after } 35 \text { days } \\
\text { Root formation after } 35 \text { days }\end{array}$ & $40.0 \pm 2.9^{\mathrm{a}}$ & NR & $20.0 \pm 3.5^{\mathrm{a}}$ \\
\hline 1.0 & 0.0 & Shoot formation after 60 days & NR & $20.0 \pm 0.6^{\mathrm{a}}$ & NR \\
\hline 2.0 & 0.0 & Shoot formation after 60 days & NR & $20.0 \pm 2.9^{\mathrm{a}}$ & NR \\
\hline 0.5 & 0.5 & Yellowish callus formation after 30 days & $93.3 \pm 0.6^{\mathrm{h}}$ & NR & NR \\
\hline 1.0 & 0.5 & Greenish callus formation after 30 days & $93.3 \pm 1.7^{\mathrm{h}}$ & NR & NR \\
\hline 1.5 & 0.5 & Yellowish callus formation after 18 days & $60.0 \pm 1.6^{\mathrm{cd}}$ & NR & NR \\
\hline 2.0 & 0.5 & Brown callus formation after 25 days & $53.3 \pm 4.0^{\mathrm{bc}}$ & NR & NR \\
\hline 0.5 & 1.0 & Yellowish callus formation after 30 days & $66.7 \pm 1.2^{\mathrm{de}}$ & NR & NR \\
\hline 1.0 & 1.0 & Yellowish callus formation after 22 days & $40.0 \pm 1.6^{\mathrm{a}}$ & NR & NR \\
\hline 1.5 & 1.0 & Yellowish callus formation after 25 days & $40.0 \pm 6.4^{\mathrm{a}}$ & NR & NR \\
\hline 2.0 & 1.0 & Yellow callus formation after 20 days & $60.0 \pm 1.2^{\mathrm{cd}}$ & NR & NR \\
\hline 0.5 & 1.5 & Green callus formation after 25 days & $60.0 \pm 6.6^{\mathrm{cd}}$ & NR & NR \\
\hline 1.0 & 1.5 & $\begin{array}{l}\text { Brown callus formation after } 25 \text { days } \\
\text { Shoot formation after } 55 \text { days }\end{array}$ & $86.7 \pm 1.8^{\mathrm{gh}}$ & $20.0 \pm 1.2^{\mathrm{a}}$ & NR \\
\hline 1.5 & 1.5 & Yellow callus formation after 25 days & $66.5 \pm 3.5^{\mathrm{de}}$ & NR & NR \\
\hline 2.0 & 1.5 & $\begin{array}{l}\text { Yellow callus formation after } 30 \text { days } \\
\text { Root formation after } 50 \text { days }\end{array}$ & $46.7 \pm 1.2^{\mathrm{ab}}$ & NR & $20.0 \pm 1.2^{\mathrm{a}}$ \\
\hline 0.5 & 2.0 & Yellow callus formation after 16 days & $46.7 \pm 2.9^{\mathrm{ab}}$ & NR & NR \\
\hline 1.0 & 2.0 & $\begin{array}{l}\text { Greenish callus formation after } 18 \text { days } \\
\text { Shoot formation after } 55 \text { days }\end{array}$ & $80.0 \pm 8.6^{\mathrm{fg}}$ & $20.0 \pm 4.6^{\mathrm{a}}$ & NR \\
\hline 1.5 & 2.0 & Yellowish callus formation after 18 days & $66.7 \pm 1.7^{\mathrm{de}}$ & NR & NR \\
\hline 2.0 & 2.0 & Yellowish callus formation after 16 days & $73.3 \pm 1.7^{\mathrm{ef}}$ & NR & NR \\
\hline 3.0 & 3.0 & Yellow callus formation after 30 days & $60.0 \pm 3.2^{\mathrm{cd}}$ & NR & NR \\
\hline
\end{tabular}

Mean \pm SE, $n=30$. Mean values with different letters in the same column are significantly different at $P<0.05$ (NR: no response).

$30 \mathrm{gL}^{-1}$ sucrose and $8 \mathrm{gL}^{-1}$ agar. After four weeks, the stem, root, and leaf explants were cut into small pieces $\left(3 \mathrm{~mm}^{2}\right)$ and cultured on MS media with 22 different combinations and concentrations of $\alpha$-naphthaleneacetic acid (NAA) and 6-benzyl aminopurine (BAP).

Each treatment was conducted in thirty replicates. The $\mathrm{pH}$ of the media was adjusted to 5.8 and autoclaved at $104 \mathrm{kPa}\left(15 \mathrm{Psi}^{2}\right)$ and $121^{\circ} \mathrm{C}$ for 21 minutes. All cultures were maintained in a culture room at $25 \pm 1^{\circ} \mathrm{C}$, with a 16-hour photoperiod with $1.496 \mathrm{~W} \mathrm{~m}^{-2}$ of light intensity. Subcultures were performed every 21-28 days to provide new and fresh nutrients under the same conditions.

\subsection{Effects of Different Concentrations of Sucrose, Photope-} riod, and $\mathrm{pH}$ of Media on Callogenesis and Organogenesis of Citrus assamensis. Different explants of Citrus assamensis were transferred onto solid MS media supplemented with optimum hormone combination $\left(1.5 \mathrm{mgL}^{-1} \mathrm{NAA}\right.$ and $2.0 \mathrm{mgL}^{-1}$ BAP) but with varied sucrose concentrations $\left(10 \mathrm{gL}^{-1}, 20 \mathrm{gL}^{-1}, 30 \mathrm{gL}^{-1}, 40 \mathrm{gL}^{-1}\right.$, or $\left.50 \mathrm{gL}^{-1}\right)$ and $\mathrm{pH}(4.8$, $5.8,6.8,7.8$, or 8.8$)$. Cultures were maintained at $25 \pm 1^{\circ} \mathrm{C}$ with 16 hours of light and 8 hours of darkness. Both experiments were conducted in thirty replicates. The effect of both sucrose concentrations and $\mathrm{pH}$ of the media on tissue culture of Citrus assamensis was monitored.

To study the effect of photoperiod on in vitro regeneration of Citrus assamensis, different explants of this species were cultured on MS media supplemented with $1.5 \mathrm{mgL}^{-1} \mathrm{NAA}$ and $2.0 \mathrm{mgL}^{-1} \mathrm{BAP}, 30 \mathrm{gL}^{-1}$ sucrose, at $\mathrm{pH}$ 5.8. The cultures however were maintained under different light or photoperiod conditions, such as under 24 hours of darkness, 8 hours of light and 16 hours of darkness, 12 hours of light and 12 hours of darkness, 16 hours of light and 8 hours of darkness, and 24 hours of light.

\subsection{Morphology and Anatomy of In Vivo and Ex Vitro Citrus} assamensis Plants. Scanning electron microscope (SEM) was used to observe the differences between in vivo (intact) and in vitro leaves of Citrus assamensis. Number of stomata and trichomes present on adaxial and abaxial surfaces of the leaves were compared. Standard method and procedure for preparation of samples for scanning electron microscopy as described by Islam et al. [7] were followed. 
TABLE 3: The effects of different combinations and concentrations of BAP and NAA on leaf explants of Citrus hybrids, cultured on solid MS media at $25 \pm 1^{\circ} \mathrm{C}$. Cultures were maintained at 16 hours of light and 8 hours of darkness, with 1000 lux intensity of light.

\begin{tabular}{|c|c|c|c|c|c|}
\hline \multicolumn{2}{|c|}{ MS + hormone } & \multirow{2}{*}{ Observations } & \multirow{2}{*}{ Callus (\%) } & \multicolumn{2}{|c|}{ Organogenesis } \\
\hline $\operatorname{BAP}\left(\mathrm{mgL}^{-1}\right)$ & NAA $\left(\mathrm{mgL}^{-1}\right)$ & & & Shoot $(\%)$ & Root $(\%)$ \\
\hline 0.0 & 1.0 & Root formation after 30 days & NR & NR & $26.7 \pm 2.3^{\mathrm{a}}$ \\
\hline 0.0 & 2.0 & Root formation after 30 days & NR & NR & $53.3 \pm 1.2^{\mathrm{b}}$ \\
\hline 1.0 & 0.0 & No response & NR & NR & NR \\
\hline 2.0 & 0.0 & No response & NR & NR & NR \\
\hline 0.5 & 0.5 & No response & NR & NR & NR \\
\hline 1.0 & 0.5 & No response & NR & NR & NR \\
\hline 1.5 & 0.5 & Green callus formation after 35 days & $20.0 \pm 1.2^{\mathrm{a}}$ & NR & NR \\
\hline 2.0 & 0.5 & Green callus formation after 40 days & $26.7 \pm 2.9^{\mathrm{a}}$ & NR & NR \\
\hline 0.5 & 1.0 & Green callus formation after 45 days & $20.0 \pm 1.7^{\mathrm{a}}$ & NR & NR \\
\hline 1.0 & 1.0 & No response & NR & NR & NR \\
\hline 1.5 & 1.0 & Yellowish callus formation after 50 days & $20.0 \pm 1.2^{\mathrm{a}}$ & NR & NR \\
\hline 2.0 & 1.0 & No response & NR & NR & NR \\
\hline 0.5 & 1.5 & Green callus formation after 38 days & $20.0 \pm 4.0^{\mathrm{a}}$ & NR & NR \\
\hline 1.0 & 1.5 & Green callus formation after 30 days & $20.0 \pm 0.5^{\mathrm{a}}$ & NR & NR \\
\hline 1.5 & 1.5 & No response & NR & NR & NR \\
\hline 2.0 & 1.5 & No response & NR & NR & NR \\
\hline 0.5 & 2.0 & No response & NR & NR & NR \\
\hline 1.0 & 2.0 & Green callus formation after 50 days & $20.0 \pm 2.7^{\mathrm{a}}$ & NR & NR \\
\hline 1.5 & 2.0 & Green callus formation after 40 days & $20.0 \pm 1.7^{\mathrm{a}}$ & NR & NR \\
\hline 2.0 & 2.0 & Green callus formation after 40 days & $26.7 \pm 2.3^{\mathrm{a}}$ & NR & NR \\
\hline 3.0 & 3.0 & No response & NR & NR & NR \\
\hline
\end{tabular}

Mean \pm SE, $n=30$. Mean values with different letters in the same column are significantly different at $P<0.05$ (NR: no response).

2.4. Statistical Analysis. Randomized complete block design (RCBD) was employed in all experiment. Data analysis was conducted through analysis of variance and Duncan's multiple range test (DMRT) at 5\% significance level.

\section{Results and Discussion}

3.1. In Vitro Regeneration of Citrus assamensis. In general, all explant cultures (stem, root, or leaf) had the potential to generate callus although stem and root explants were found to be more responsive than leaf explants. The highest callus formation was produced from cultures supplemented with $1.5 \mathrm{mgL}^{-1} \mathrm{NAA}$ and $0.5 \mathrm{mgL}^{-1} \mathrm{BAP}$, whereby $100 \%, 60 \%$, and $20 \%$ of stem, root, and leaf explants had produced callus, respectively (Tables 1, 2, and 3). MS media added with other hormone combinations were also found to yield production of callus, such as $1.0 \mathrm{mgL}^{-1} \mathrm{NAA}$ and $0.5 \mathrm{mgL}^{-1} \mathrm{BAP}$ as well as $2.0 \mathrm{mgL}^{-1} \mathrm{NAA}$ and $2.0 \mathrm{mgL}^{-1}$ BAP (Tables 1-3). Stem explants were the most responsive for callus induction, yielding light green callus after only 20 days of culture (Figure 1). Green callus was also produced from leaf cultures after 40 to 50 days (Figure 1) although the explant type was the least responsive. However, root explants were found to yield a mixture of yellow (Figure 1) and green callus. Comparable results were obtained by Mukhri and Yamaguchi [8], whereby formation of callus was reported from Curcuma domestica rhizomes when the regeneration media were supplemented with BAP and 2,4-D combined as well as BAP and NAA combined. On the other hand, organogenesis was yielded when $C$. domestica rhizomes were cultured on Ringe and Nitsch [9] medium added with only BAP.

Direct regeneration of shoots was produced from stem and root cultures, while leaf cultures showed limited organogenesis potential. The highest percentage of shoot formation (46.7\%) was achieved when stem explants were cultured on MS media supplemented with $1.5 \mathrm{mgL}^{-1} \mathrm{NAA}$ and $2.0 \mathrm{mgL}^{-1}$ BAP (Figure 1). It was also observed that high cytokinin (BAP) levels $\left(2.0 \mathrm{mgL}^{-1}\right)$ aided the formation of shoots from explant cultures, compared to when low levels of cytokinin $\left(1.0 \mathrm{mgL}^{-1} \mathrm{BAP}\right)$ were used. Formation of roots occurred readily from stem, root, and leaf explants cultured on MS media supplemented with $1.0 \mathrm{mgL}^{-1}$ and $2.0 \mathrm{mgL}^{-1}$ NAA. It was observed that root explants were the most responsive, yielding formation of roots within 18 days of culture compared to other explant types, which showed rooting after approximately 30 days. Furthermore, it was found that rooting occurred faster (18 days) when high auxin (NAA) concentrations $\left(2.0 \mathrm{mgL}^{-1}\right)$ were used compared to 30 days, when low NAA concentrations $\left(1.0 \mathrm{mgL}^{-1}\right)$ were used. Induction of rooting from leaf explant and production of multiple shoots from stem explant were depicted in Figure 1.

In general, tissue culture technology can be applied onto all plant species due to the basis that all plant parts can be utilized as explants. However, previous research suggested that herbaceous plants are generally more responsive and 
TABLE 4: The effects of different concentrations of sucrose on stem, root, and leaf explants, cultured on optimum media (MS $+1.5 \mathrm{mgL} \mathrm{L}^{-1} \mathrm{NAA}$ $\left.+2.0 \mathrm{mgL}^{-1} \mathrm{BAP}\right)$ at $25 \pm 1^{\circ} \mathrm{C}$. Cultures were maintained at 16 hours of light and 8 hours of darkness, with 1000 lux intensity of light.

\begin{tabular}{|c|c|c|c|c|c|}
\hline \multirow{2}{*}{ Concentrations of sucrose $\left(\mathrm{gL}^{-1}\right)$} & \multirow{2}{*}{ Explants } & \multirow{2}{*}{ Observations } & \multirow{2}{*}{ Callus (\%) } & \multicolumn{2}{|c|}{ Organogenesis } \\
\hline & & & & Shoot $(\%)$ & Root $(\%)$ \\
\hline \multirow{3}{*}{20} & Stem & Shoots formation after 60 days & NR & $26.7 \pm 1.2^{\mathrm{a}}$ & NR \\
\hline & Root & Green callus formation after 50 days & $20.0 \pm 1.7^{\mathrm{a}}$ & NR & NR \\
\hline & Leaf & No response & NR & NR & NR \\
\hline \multirow{3}{*}{30} & Stem & $\begin{array}{l}\text { Green callus formation after } 25 \text { days } \\
\text { Shoots formation after } 30 \text { days }\end{array}$ & $33.3 \pm 1.2^{\mathrm{a}}$ & $46.7 \pm 1.7^{\mathrm{b}}$ & NR \\
\hline & Root & Yellow callus formation after 30 days & $46.7 \pm 1.7^{\mathrm{c}}$ & NR & NR \\
\hline & Leaf & No response & NR & NR & NR \\
\hline \multirow{3}{*}{40} & Stem & Shoots formation after 50 days & NR & $30.0 \pm 2.9^{\mathrm{a}}$ & NR \\
\hline & Root & Green callus formation after 40 days & $30.0 \pm 3.5^{\mathrm{b}}$ & NR & NR \\
\hline & Leaf & No response & NR & NR & NR \\
\hline \multirow{3}{*}{50} & Stem & $\begin{array}{l}\text { Green callus formation after } 40 \text { days } \\
\text { Shoots formation after } 50 \text { days }\end{array}$ & $66.7 \pm 3.5^{\mathrm{b}}$ & $26.7 \pm 1.2^{\mathrm{a}}$ & NR \\
\hline & Root & Yellow callus formation after 40 days & $46.7 \pm 2.0^{c}$ & NR & NR \\
\hline & Leaf & No response & NR & NR & NR \\
\hline
\end{tabular}

Mean \pm SE, $n=30$. Mean values with different letters (subject to different explant type) in the same column are significantly different at $P<0.05$ (NR: no response).

TABLE 5: The effects of different $\mathrm{pH}$ on stem, root, and leaf explants, cultured on optimum media $\left(\mathrm{MS}+1.5 \mathrm{mgL}^{-1} \mathrm{NAA}+2.0 \mathrm{mgL}^{-1} \mathrm{BAP}\right)$ at $25 \pm 1^{\circ} \mathrm{C}$. Cultures were maintained at 16 hours of light and 8 hours of darkness, with 1000 lux intensity of light.

\begin{tabular}{|c|c|c|c|c|c|}
\hline \multirow{2}{*}{$\mathrm{pH}$ of media } & \multirow{2}{*}{ Explants } & \multirow{2}{*}{ Observations } & \multirow{2}{*}{ Callus (\%) } & \multicolumn{2}{|c|}{ Organogenesis } \\
\hline & & & & Shoot $(\%)$ & $\operatorname{Root}(\%)$ \\
\hline \multirow{3}{*}{4.8} & Stem & Shoots formation after 45 days & NR & $33.3 \pm 1.7^{\mathrm{b}}$ & NR \\
\hline & Root & Yellow callus formation after 35 days & $33.3 \pm 1.2^{\mathrm{a}}$ & NR & NR \\
\hline & Leaf & No response & NR & NR & NR \\
\hline \multirow{3}{*}{5.8} & Stem & $\begin{array}{l}\text { Green callus formation after } 25 \text { days } \\
\text { Shoots formation after } 30 \text { days }\end{array}$ & $33.3 \pm 2.3^{\mathrm{a}}$ & $46.7 \pm 2.3^{c}$ & NR \\
\hline & Root & Yellow callus formation after 30 days & $46.7 \pm 3.5^{\mathrm{b}}$ & NR & NR \\
\hline & Leaf & No response & NR & NR & NR \\
\hline \multirow{3}{*}{6.8} & Stem & Shoots formation after 55 days & NR & $20.0 \pm 2.3^{\mathrm{a}}$ & NR \\
\hline & Root & Green callus formation after 50 days & $46.7 \pm 1.7^{\mathrm{b}}$ & NR & NR \\
\hline & Leaf & No response & NR & NR & NR \\
\hline
\end{tabular}

Mean \pm SE, $n=30$. Mean values with different letters (subject to different explant type) in the same column are significantly different at $P<0.05$ (NR: no response).

easily propagated via tissue culture protocols compared to woody plants. According to Abbot [10], woody plants exhibited lower propagation potential due to their complex and long life cycle. Clonal multiplication from mature tissues or organs of woody plants was difficult [11, 12]. Robb [13] stated that shoots of woody plants had long dormancy time than herbaceous plants; hence limited reports were found on successful in vitro propagation of woody plants.

Induction of callus often occurs at the wound site or the area from which the explant was cut, as shown by callus production from Cucumis sativus, Cucumis melo, and Cucumis metuliferus [14]. NAA and BAP when used in combination would encourage cell division [15]. Upadhyang et al. [16] also reported similar observations in Rauvolfia caffra, where $2.0 \mathrm{mgL}^{-1} \mathrm{NAA}$ and $2.0 \mathrm{mgL}^{-1}$ BAP combined were most effective for production of callus. The use of auxin NAA was also beneficial in induction of rooting in tissue culture [14]. Induction of roots from shoot explants in woody plants occurred faster in growth media supplemented with IAA compared to when NAA was used [17].

The effect of sucrose concentrations, $\mathrm{pH}$ of the media, and photoperiod on tissue culture of Citrus hybrids was also studied. It was found that shoot formation was optimum when the media were supplemented with $30 \mathrm{gL}^{-1}$ and $40 \mathrm{gL}^{-1}$ sucrose (Table 4). Production of callus was the highest in stem and root cultures supplemented with $50 \mathrm{gL}^{-1}$ sucrose (Table 4). However, it was observed that shoot and callus formation occurred faster (25 to 30 days) in media added with $30 \mathrm{gL}^{-1}$ 
TABLE 6: The effects of light exposure on stem, root, and leaf explants, cultured on optimum media (MS $+1.5 \mathrm{mgL}^{-1} \mathrm{NAA}+2.0 \mathrm{mgL} \mathrm{BAP}^{-1}$ at $25 \pm 1^{\circ} \mathrm{C}$. Cultures were maintained at 16 hours of light and 8 hours of darkness, with 1000 lux intensity of light.

\begin{tabular}{|c|c|c|c|c|c|c|}
\hline \multicolumn{2}{|c|}{ Light exposure (hrs) } & \multirow{2}{*}{ Explant } & \multirow{2}{*}{ Observations } & \multirow{2}{*}{ Callus (\%) } & \multicolumn{2}{|c|}{ Organogenesis } \\
\hline Light & Darkness & & & & Shoot $(\%)$ & Root $(\%)$ \\
\hline \multirow{3}{*}{0} & \multirow{3}{*}{24} & Stem & White callus formation after 12 days & $73.3 \pm 4.6^{\mathrm{b}}$ & NR & NR \\
\hline & & Root & White callus formation after 35 days & $46.7 \pm 2.3^{\mathrm{a}}$ & NR & NR \\
\hline & & Leaf & No response & NR & NR & NR \\
\hline \multirow{3}{*}{8} & \multirow{3}{*}{16} & Stem & Multiple shoots formation after 16 days & NR & $20.0 \pm 1.7^{\mathrm{a}}$ & NR \\
\hline & & Root & Yellow callus formation after 40 days & $40.0 \pm 1.7^{\mathrm{a}}$ & NR & NR \\
\hline & & Leaf & No response & NR & NR & NR \\
\hline \multirow{3}{*}{12} & \multirow{3}{*}{12} & Stem & $\begin{array}{l}\text { Green callus formation after } 45 \text { days } \\
\text { Shoots formation after } 50 \text { days }\end{array}$ & $40.0 \pm 1.7^{\mathrm{a}}$ & $40.0 \pm 2.3^{\mathrm{bc}}$ & NR \\
\hline & & Root & Green callus formation after 25 days & $86.7 \pm 1.2^{\mathrm{c}}$ & NR & NR \\
\hline & & Leaf & No response & NR & NR & NR \\
\hline \multirow{3}{*}{16} & \multirow{3}{*}{8} & Stem & $\begin{array}{l}\text { Green callus formation after } 25 \text { days } \\
\text { Shoots formation after } 50 \text { days }\end{array}$ & $33.3 \pm 2.3^{\mathrm{a}}$ & $46.7 \pm 5.2^{\mathrm{c}}$ & NR \\
\hline & & Root & Yellow callus formation after 30 days & $46.7 \pm 3.5^{\mathrm{a}}$ & NR & NR \\
\hline & & Leaf & No response & NR & NR & NR \\
\hline \multirow{3}{*}{24} & \multirow{3}{*}{0} & Stem & Multiple shoots formation after 14 days & NR & $33.3 \pm 1.7^{\mathrm{b}}$ & NR \\
\hline & & Root & Green yellow formation after 30 days & $60.0 \pm 2.3^{\mathrm{b}}$ & NR & NR \\
\hline & & Leaf & No response & NR & NR & NR \\
\hline
\end{tabular}

Mean \pm SE, $n=30$. Mean values with different letters (subject to different explant type) in the same column are significantly different at $P<0.05$ (NR: no response).

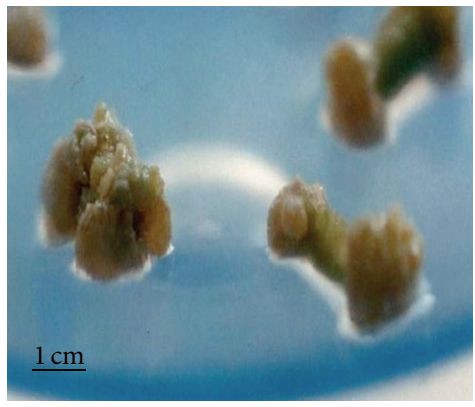

(a)

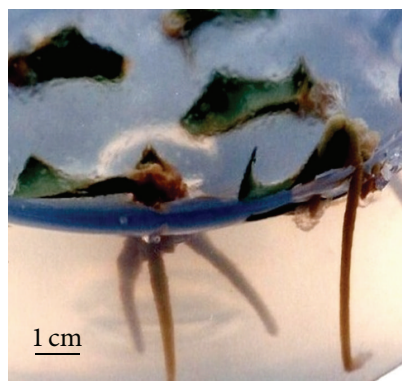

(d)

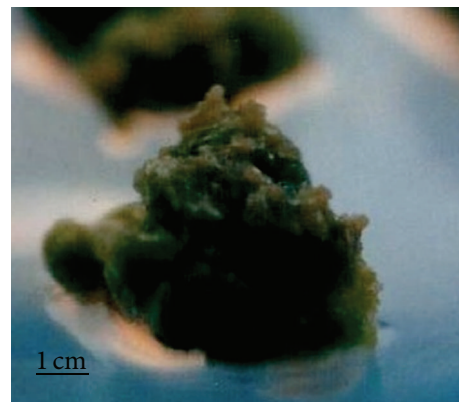

(b)

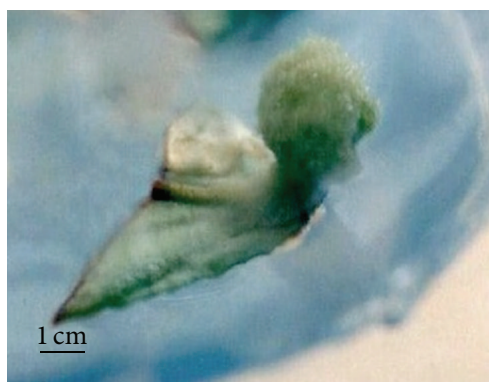

(e)

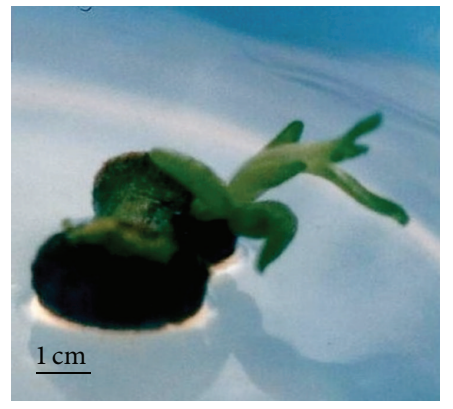

(c)

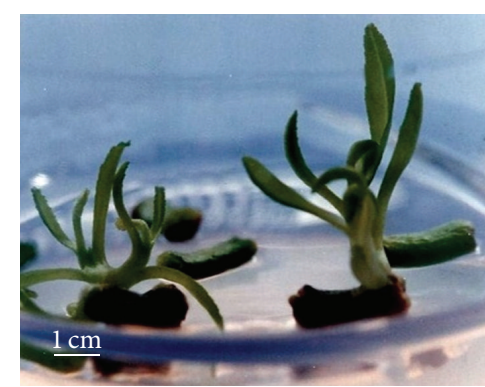

(f)

FIGURE 1: Various explants cultured on optimum regeneration media (MS media supplemented with $1.5 \mathrm{mgL}^{-1} \mathrm{NAA}$ and $2.0 \mathrm{mgL}^{-1} \mathrm{BAP}$ ), maintained under 16 hours of light and 8 hours of darkness, with light intensity of 1000 lux. (a) Formation of yellow callus from root explant, (b) formation of green callus from root explant, (c) formation of green callus and production of shoot primordia from stem explant, (d) formation of roots from leaf explant after 18 days of culture, (e) formation of green callus from leaf explant, and (f) formation of multiple shoots from stem explant. 


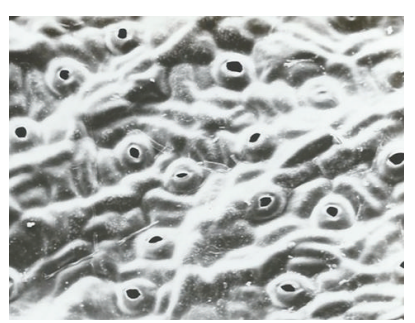

(a)

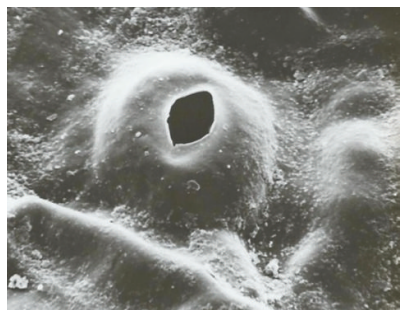

(e)

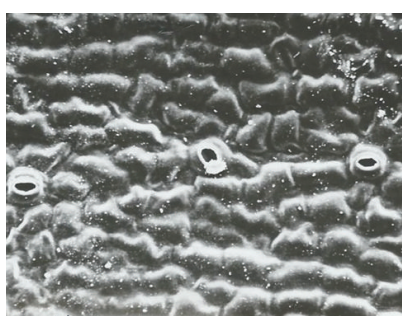

(i)

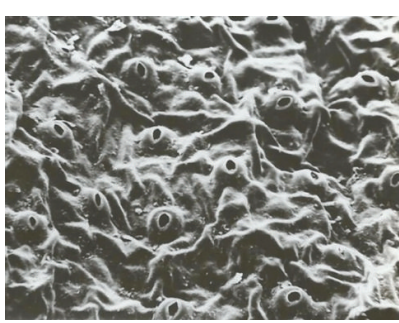

(b)

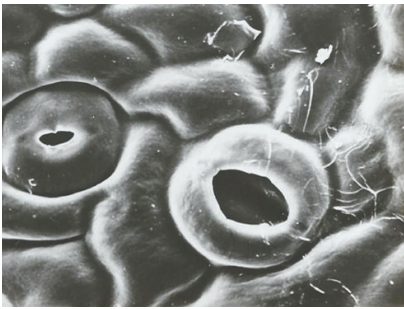

(f)

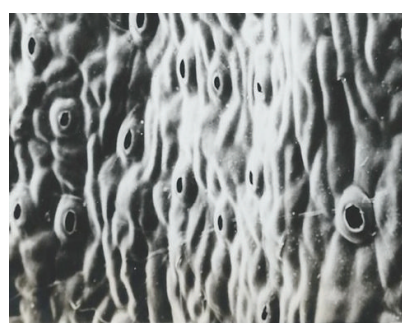

(j)

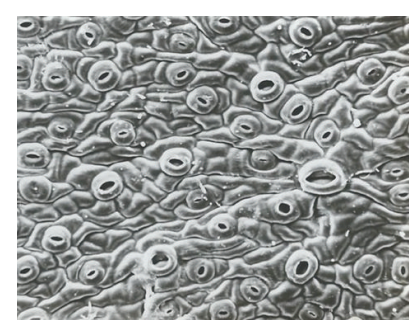

(c)

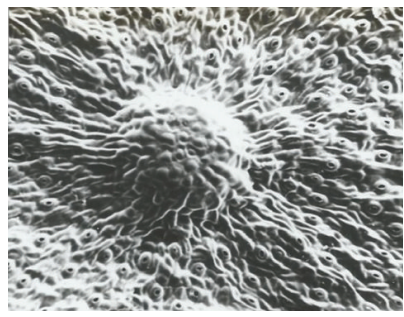

(g)

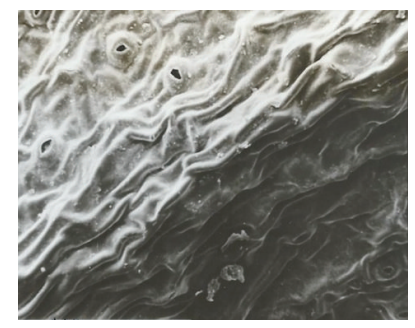

$(\mathrm{k})$

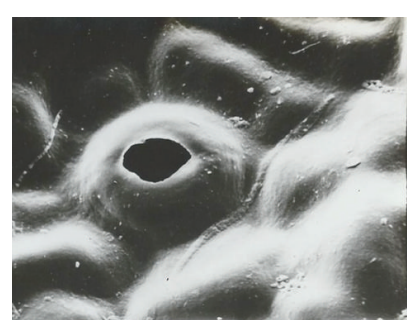

(d)

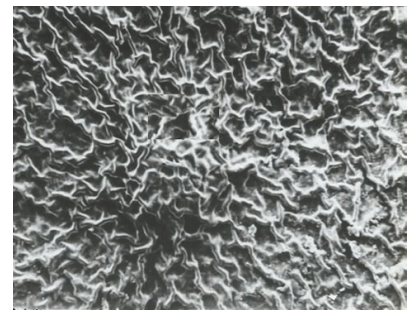

(h)

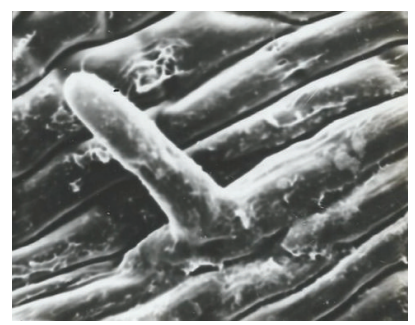

(l)

FIGURE 2: Scanning electron micrographs (SEM) of in vivo and in vitro grown Citrus assamensis leaves. (a) Abaxial surface of in vitro and (b) in vivo grown leaf showing anomocytic stomata; (c) abaxial surface of in vitro grown leaf, showing vivid anomocytic stomata in between lined epidermal cells; (d-e) abaxial surface of in vivo grown leaf showing clearly defined anomocytic stomata that appeared from the epidermal surface; (f) stoma of in vitro grown leaf sunk into epidermal surface; (g-h) abaxial surface of in vivo grown leaf, showing the presence of oil glands; (i) abaxial surface of in vitro grown leaf showing the absence of oil gland; ( $\mathrm{j}-\mathrm{k}$ ) lack of trichomes was observed from primary veins of in vivo grown leaf; (l) primary vein of in vitro grown leaf showing the presence of trichome.

sucrose compared to media containing $20 \mathrm{gL}^{-1}$ and $50 \mathrm{gL}^{-1}$ sucrose (40 to 50 days).

Furthermore, $\mathrm{pH}$ lower or higher than 5.8 was also found to affect formation of shoots from explant cultures. It was observed that explant cultures with $\mathrm{pH}$ of the growth media adjusted to $5.8,4.8$, and 6.8 yielded percentage of shoot formation of $46.7 \%, 33.3 \%$, and $20.0 \%$, respectively (Table 5). Shoot formation also occurred faster (30 days) in media at pH 5.8 compared to 45 to 50 days in media at pH 4.8 and 6.8 (Table 5). However, root cultures in media at $\mathrm{pH} 4.8$ showed significantly poorer formation of callus than in media at $\mathrm{pH}$ 5.8 and 6.8. Although similar percentage of callus formation $(46.7 \%)$ was recorded from root cultures in media at $\mathrm{pH} 5.8$ and 6.8, induction of callus was found to occur faster (30 days) at $\mathrm{pH} 5.8$ than at $\mathrm{pH} 6.8$ (35 days). Owen et al. [18] stated that $\mathrm{pH}$ of the media in tissue culture system can influence in vitro shoot multiplication, floral and secondary metabolites development, organogenesis, production of adventitious roots, and cell division.

Photoperiod also affects formation of shoots, multiple shoots, and callus. Percentage of shoot formation was found to increase when duration of exposure to light was increased, whereby optimum shoot formation (46.7\%) was observed when the stem cultures were maintained under 16 hours of light and 8 hours of darkness (Table 6). However, exposure to 24 hours of darkness had reduced the percentage of shoot formation to $33.3 \%$ (Table 6). The lack of light also aided callus formation, whereby stem cultures exhibited percentage of callus formation of $73.3 \%$ when stem cultures were maintained under 24 hours of darkness (Table 6).

\subsection{Morphology and Anatomy of In Vivo and In Vitro Grown} Citrus assamensis Plants. The morphology of 3-month-old in vivo and acclimatized in vitro grown Citrus assamensis plantlets was observed and compared to detect any morphological irregularities that might have occurred due to tissue culture protocols. In vivo plant was grown on soil and subjected to natural environment in the garden, while in vitro plantlets were taken out from the culture vessels and acclimatized in the greenhouse for 1 month prior to SEM and histological analysis. The mean plant height, leaf structure, leaf shape, and leaf diameter were measured and compared. Furthermore, leaf segments of Citrus assamensis 


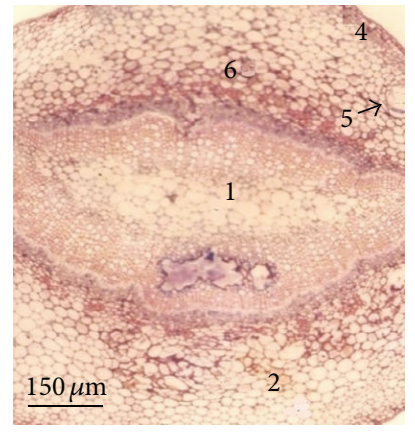

(a)

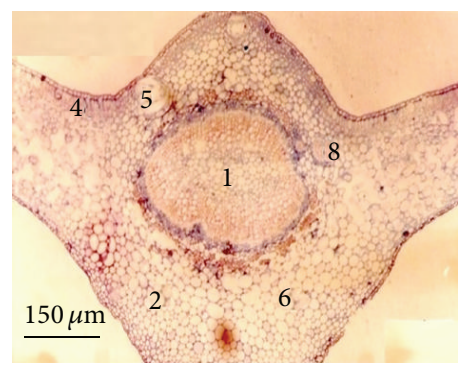

(d)

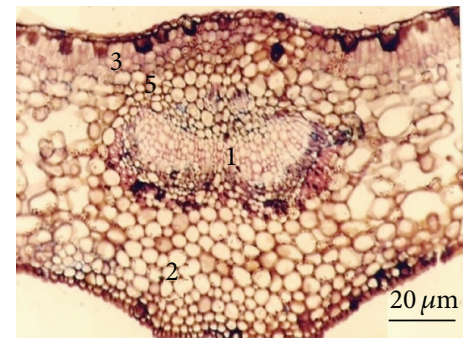

(g)

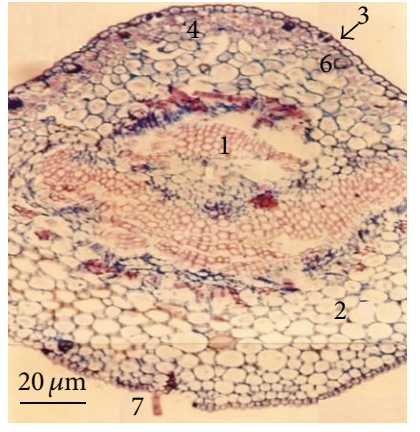

(b)

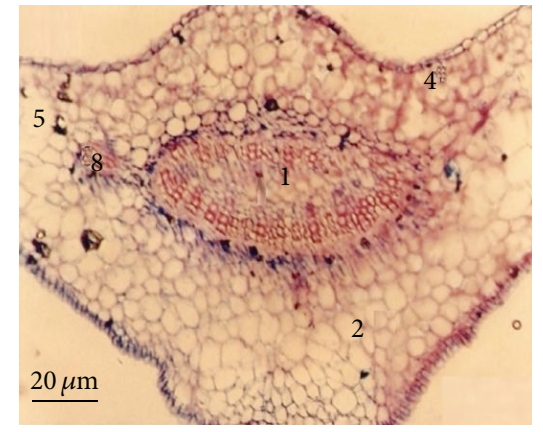

(c)

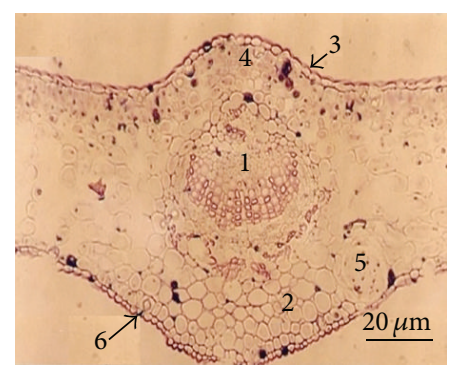

(e)

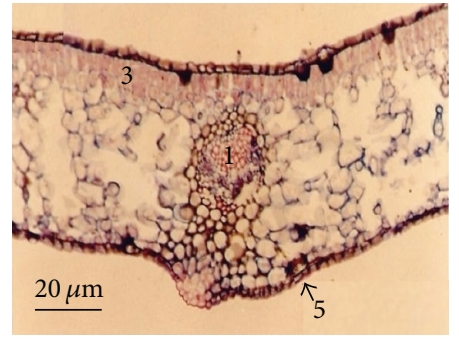

(h)

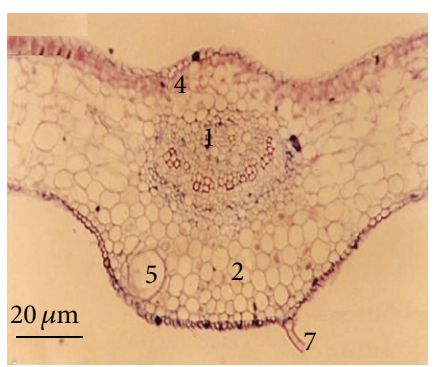

(f)

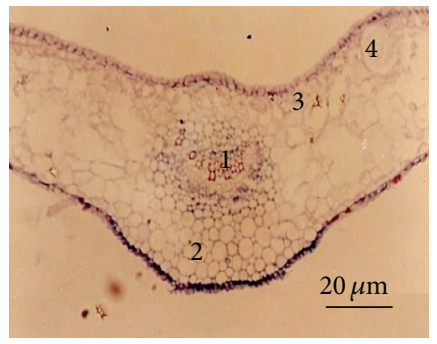

(i)

Figure 3: Histological examinations on in vivo and in vitro grown Citrus assamensis leaves. (a-c) Cross sections of leaf base of (a-b) in vivo and (c) in vitro plants, showing the presence of (1) vascular system, (2) cell structures, (3) cuticle, (4) palisade layer, (5) oil gland, (6) drusa, (7) trichome, and (8) lateral vascular bundle. (d-f) Cross sections of leaf midrib of (d-e) in vivo and (f) in vitro plants, showing the presence of (1) vascular system, (2) cell structures, (3) cuticle, (4) palisade layer, (5) oil gland, (6) drusa, (7) trichome, and (8) lateral vascular bundle. (g-i) Cross sections of leaf tip (apex) of (g-h) in vivo and (i) in vitro plants, showing the presence of (1) vascular system, (2) cell structures, (3) palisade layer, (4) oil gland, and (5) drusa.

grown in vivo and in vitro were also viewed under scanning electron microscope (SEM) (Jeol JSM-6400) to elucidate any micromorphological differences that might present, hence detecting any occurrences of somaclonal variation.

The microscopic studies of the structure of in vivo (intact) and in vitro leaves showed that the stomata apparatuses were generally anomocytic in shape. Oil glands were observed on both abaxial and adaxial surfaces of intact leaves but none on in vitro grown leaves (Figure 2). Stomata structures were observed on the abaxial surface of both in vivo and in vitro grown leaves but not on the adaxial surface (Figure 2). Interestingly, trichomes were only observed on primary veins of in vitro grown leaves (on abaxial surface) but none was present on in vivo grown leaves (Figure 2). SEM micrographs showing the stomata and trichome structures of in vivo and in vitro grown leaves of Citrus assamensis are depicted in Figure 2.

Histological studies conducted on both in vivo and in vitro grown leaves revealed that in vivo leaf had "V" shaped vascular system, with uneven hexagonal, circular, and oval shaped cells (Figure 3 ). The cuticle was observed to be thin with three layers of palisade cells (Figure 3). In vivo grown Citrus assamensis leaf also lacked oil glands, although a lot of "drusa" were present (Figure 3). On the other hand, in vitro leaf had "elliptical" vascular system, also with uneven hexagonal-, circular-, and oval-shaped cells (Figure 3). However, no cuticle layer was observed on the in vitro leaf, although two vague palisade layers appeared to be present (Figure 3). In contrast with the in vivo leaf, oil gland was present on the in vitro leaf, but "drusa" was absent.

\section{Conclusions}

Citrus assamensis can be regenerated and propagated through tissue culture technique, as clearly demonstrated in the present investigation. Young stem was the most responsive 
explant type. The highest shoot formation (46.7\%) was observed on MS medium supplemented with $1.5 \mathrm{mgL}^{-1} \mathrm{NAA}$ and $2.0 \mathrm{mgL}^{-1}$ BAP. Acclimatization of in vitro plantlets of Citrus assamensis was successful and the plantlets had survived after 2 months of being transferred to greenhouse. This process is important to examine the success of this technique in propagation of Citrus assamensis. Meanwhile, xylem and phloem tissue in the leaf vascular bundle in vivo were thicker and more complex than in in vitro leaf vascular bundle, when compared anatomically. Furthermore, SEM showed more scattered and different shape of stoma in vitro compared to in vivo. However, most of in vitro stomata were submerged compared to in vivo, where the stomata structures were observed to arise from the epidermal surface. Based on SEM and histological studies, only minor micromorphological differences were observed, with no distinct indication of somaclonal variation.

\section{Conflict of Interests}

The authors declare that there is no conflict of interests regarding the publication of this paper.

\section{Acknowledgments}

The authors would like to thank the University of Malaya, Kuala Lumpur, for the facilities and the Institute of Research Management and Monitoring (IPPP) for the financial support provided (Bantuan Kecil Penyelidikan-BKP Grant no. BK015-2013) to successfully carry out this research.

\section{References}

[1] J. L. Guardiola, "Frutificação e crescimento," in Paper Presented at 2. Seminário Internacional de Citros-Fisiologia, Bebedouro, Brazil, 1992.

[2] H. H. Hume, Citrus Fruits (Revised Edition of Cultivation of Citrus Fruits), Macmillan, New York, NY, USA, 1957.

[3] J. S. Rathore, M. S. Rathore, M. Singh, R. P. Singh, and N. S. Shekhawat, "Micropropagation of mature tree of Citrus limon," Indian Journal of Biotechnology, vol. 6, no. 2, pp. 239-244, 2007.

[4] J. W. Grosser, "In vitro culture of tropical fruits," in Plant Cell and Tissue Culture, K. Vasil and T. A. Thorpe, Eds., pp. 475496, Kluwer Academic Publishers, Dordrecht, The Netherlands, 1994.

[5] E. Primo, P. Cunat, J. L. Vaya, and J. Fernandez, "Estudio de la reducion del premature loosening naranjas "Navelate" mediate tratamientos with 2,4-D and 2,4,5-T," Agroquimica y Technologia de Alimentos, vol. 6, pp. 360-365, 1966.

[6] T. Murashige and F. Skoog, "A revised medium for rapid growth and bioassay with tobacco tissue cultures," Physiologia Plantarum, vol. 15, pp. 473-497, 1962.

[7] M. T. Islam, Y. Hashidoko, A. Deora, T. Ito, and S. Tahara, "Suppression of damping-off disease in host plants by the rhizoplane bacterium Lysobacter sp. strain SB-K88 is linked to plant colonization and antibiosis against soilborne peronosporomycetes," Applied and Environmental Microbiology, vol. 71, no. 7, pp. 3786-3796, 2005.

[8] Z. Mukhri and H. Yamaguchi, "In vitro plant multiplication from rhizomes of turmeric (Curcuma domestica Val.) and temoe lawak (C. xanthoriza Roxb.)," Plant Tissue Culture Letters, vol. 3, no. 1, pp. 28-30, 1986.

[9] F. Ringe and J. P. Nitsch, "Conditions leading to flower formation on excised Begonia fragments cultured in vitro," Plant Cell Physiology, vol. 9, pp. 639-652, 1968.

[10] A. J. Abbot, "Propagating temperate woody species in tissue culture," Scientia Horticulturae, vol. 28, pp. 155-162, 1977.

[11] O. P. Jones, M. E. Hopgood, and D. O. Farrel, "Propagating in vitro of M. 26 apple rootstocks," Journal of Horticultural Science, vol. 52, pp. 235-238, 1977.

[12] R. L. Mott, “Trees," in Principles and Practices of Cloning Agricultural Plants via In Vitro Techniques, B. V. Conger, Ed., pp. 217-254, CRS Press, Boca Raton, Fla, USA, 1981.

[13] S. M. Robb, "The culture of excised tissue 3Lilium speciosumthun," Journal of Experimental Botany, vol. 8, no. 3, pp. 348352, 1957.

[14] Z. K. Punja, N. Abbas, G. G. Sarmento, and F. A. Tang, "Regeneration of Cucumis sativus var. sativus and C. sativus var. hardwickii, C. melo, and C. metuliferus from explants through somatic embryogenesis and organogenesis - Influence of explant source, growth regulator regime and genotype," Plant Cell, Tissue and Organ Culture, vol. 21, no. 2, pp. 93-102, 1990.

[15] C. K. H. Teo, Pengenalan Teknologi Kultur Tisu Tumbuhan, Universiti Sains Malaysia, 1990.

[16] N. Upadhyang, Y. Makoveychuk, L. A. Nikolaeva, and T. B. Batygina, "Organogenesis and somatic embryogenesis in leaf callus culture of Rauwolfia caffra sond," Journal of Plant Physiology, vol. 140, pp. 218-222, 1992.

[17] I. M. Sulaiman and C. R. Babu, "In vitro regeneration through organogenesis of Meconopsis simplicifolia-an endangered ornamental species," Plant Cell, Tissue and Organ Culture, vol. 34, no. 3, pp. 295-298, 1993.

[18] H. R. Owen, D. Wengerd, and A. R. Miller, "Culture medium $\mathrm{pH}$ is influenced by basal medium, carbohydrate source, gelling agent, activated charcoal, and medium storage method," Plant Cell Reports, vol. 10, no. 11, pp. 583-586, 1991. 

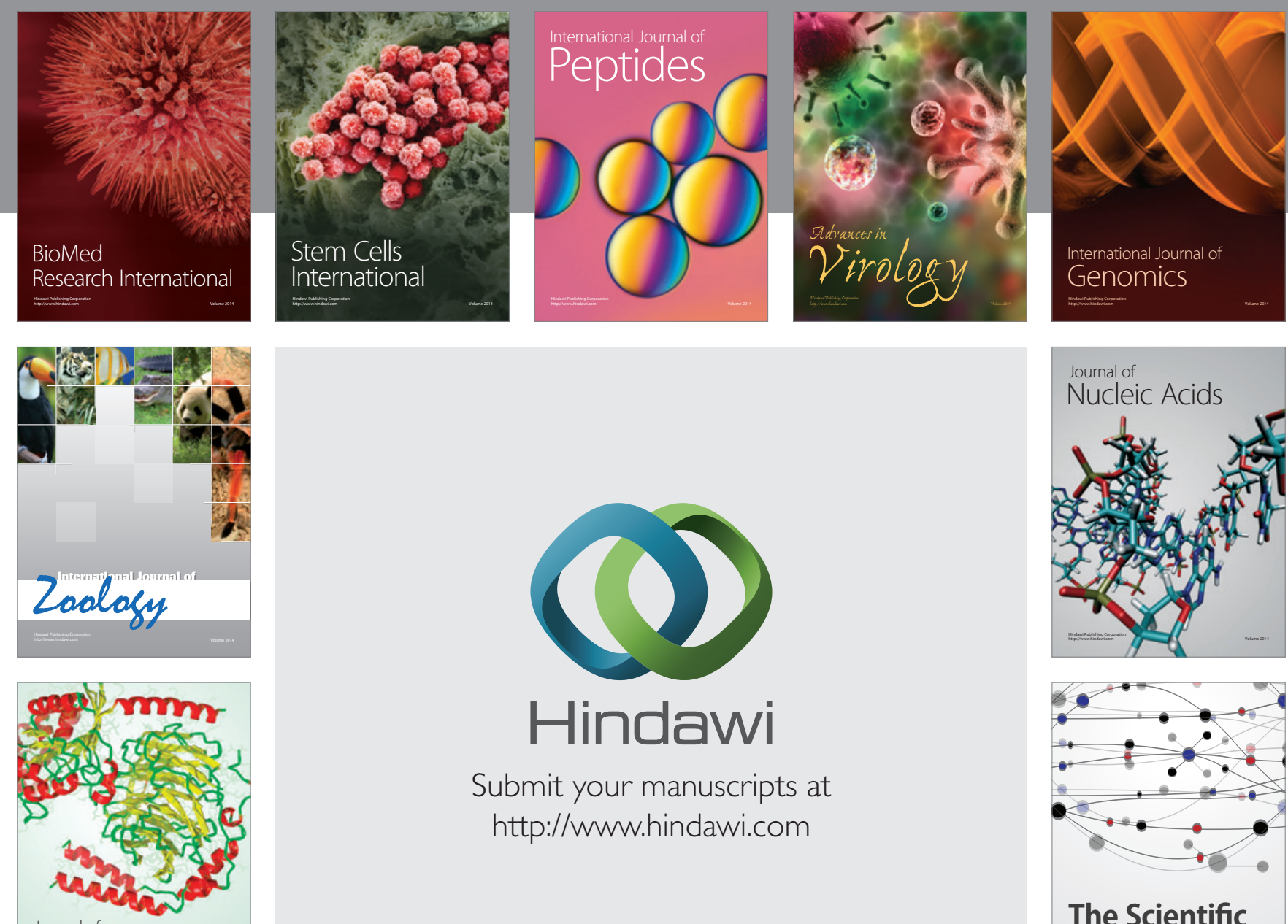

Submit your manuscripts at

http://www.hindawi.com

Journal of
Signal Transduction
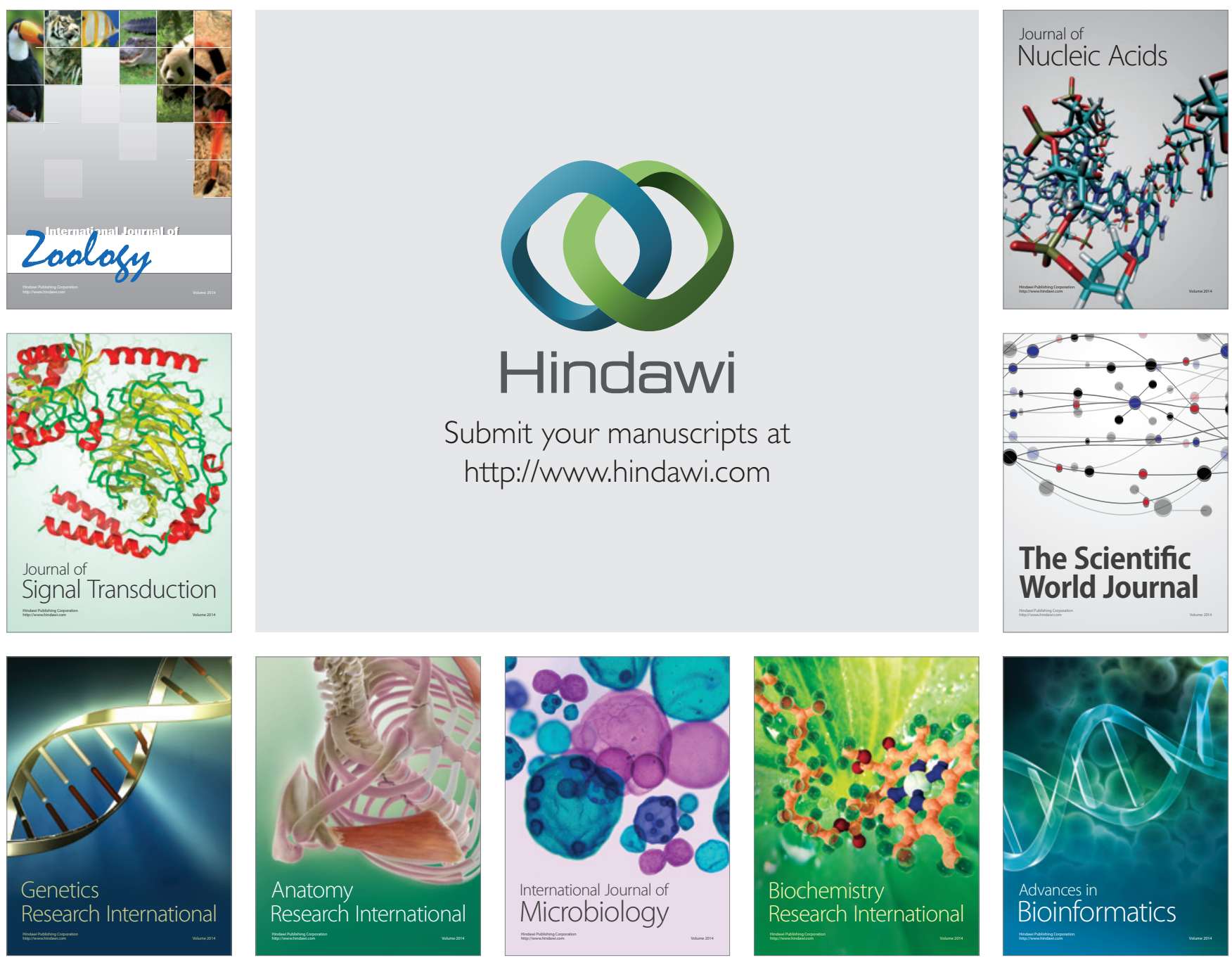

The Scientific World Journal
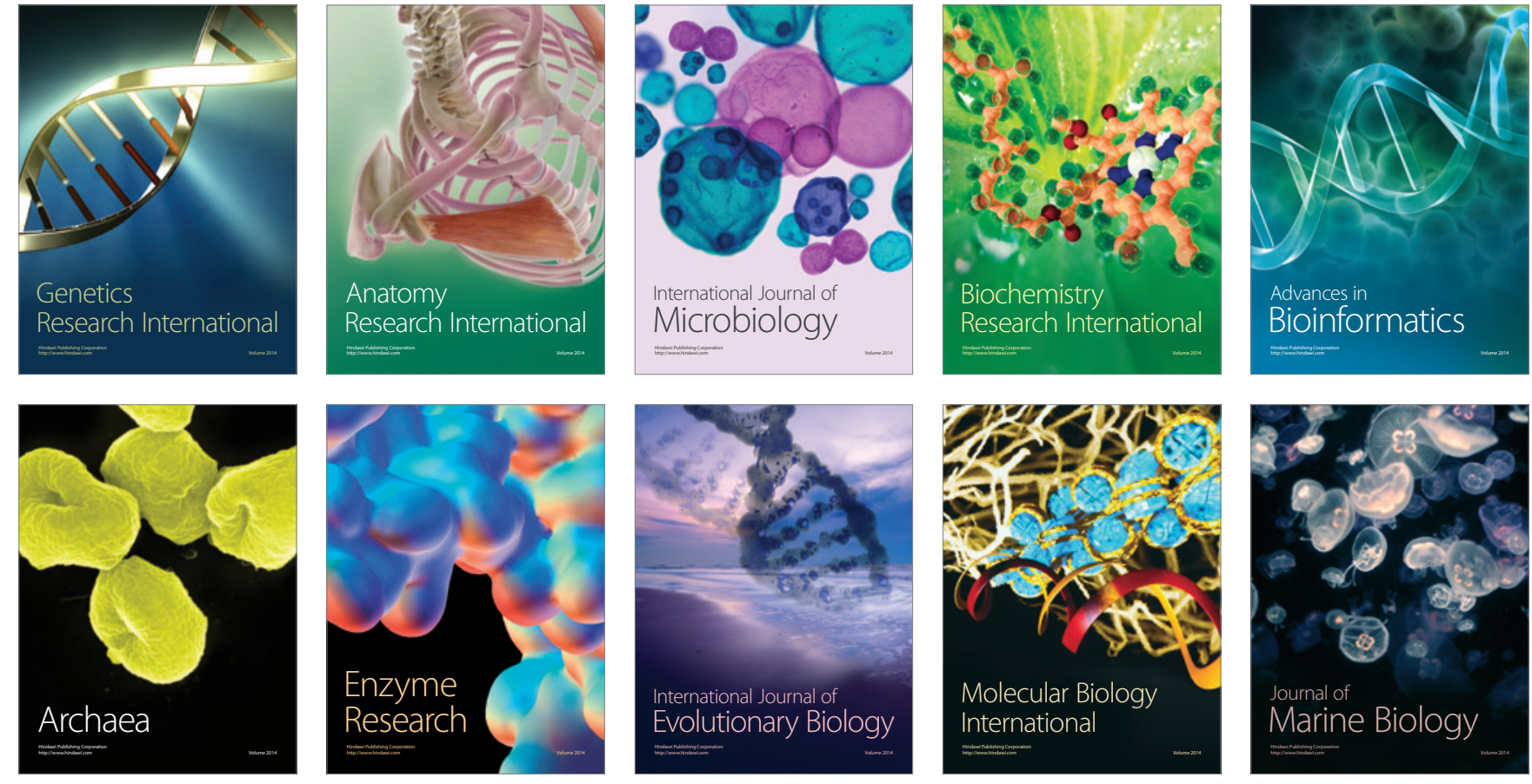